In Bio-based Composites For High-performance Materials: From Strategy To Industrial Application. Chap. 6. pp 87-112 2015

Eds Wirasak Smitthipong, Rungsima Chollakup, Michel Nardin, Crc

Press-taylor \& Francis Group

https://archimer.ifremer.fr/doc/00749/86084/

\title{
Reinforcement of Polymers by Flax Fibers: Role of Interfaces
}

\author{
Baley Christophe ${ }^{1}$, Le Duigou Antoine ${ }^{1}$, Bourmaud Alain ${ }^{1}$, Davies Peter ${ }^{2}$, Nardin Michel ${ }^{3}$, \\ Morvan Claudine ${ }^{4}$
}

1 Université Bretagne Sud, LIMATB, Rue de Saint Maudé BP 92116, 56321 Lorient Cedex, France
2 IFREMER, Marine Structures group, Centre de Bretagne, BP70, 29280 Plouzané, France
3 Institut de Sciences des Matériaux de Mulhouse, UMR-CNRS 7361, Université de Haute Alsace, 15
rue Jean Starcky, 68057 Mulhouse Cedex, France
4 Université de Rouen, Laboratoire PBS, UMR 6270 CNRS, FR 3038, 76821 Mont-Saint- Aignan Cedex,
France

\begin{abstract}
:
The use of natural fibers to reinforce composite materials is justified based on sustainable development that enables local resources to be used. Use of these fibers can act as a vector for socioeconomic development in non-industrial countries.
\end{abstract}




\section{Introduction}

The use of natural fibres to reinforce composite materials is usually justified based on sustainable development as it enables local resources to be used; this can be a vector for socio-economic development in non-industrial countries.

Plant fibres are noble materials which have been produced and recycled naturally for millions of years (biodegradable materials renewed through plant growth); their use as a composite reinforcement results in environmental benefits which can be shown by life cycle analyses [1-4]. Components made from biocomposites with a thermoplastic matrix can be recycled [5-7] and, if the matrix is biodegradable (biopolymers), they can be composted after grinding $[8,9]$.

Elementary flax fibres (Linum usitatissimum) have a complex structure and composition related to their role within the plant. Their structure is comparable to that of a composite material. There are therefore interfaces to be identified and studied. Flax fibres [10-16] show high quasi-static tensile properties $(\mathrm{E}=60.4 \mathrm{GPa}, \sigma=1262 \mathrm{MPa}$ and $\varepsilon=2.2 \%$ are mean values based on tests performed by the authors over the last ten years), comparable to those for glass fibres, and this justifies their use as a reinforcement for composite materials. These mechanical properties vary and a simple explanation for this variability is the genetic factors (which depend on the choice of variety), the agronomic practices and the environment. It is possible to correlate, using micromechanics expressions, the mean tensile properties of elementary flax fibres with those of a unidirectional ply [17], by accounting for the fibre and matrix properties, the quality of the fibre/matrix adherence, the fibre volume fraction and the distribution of fibres in the matrix (separation and distribution of fibres).

Several parameters influence the properties of composite materials. Obviously, the intrinsic mechanical properties of the matrix and the fibres play a key role. The fibre / matrix interface 
strength is also crucial in ensuring load transfer from the matrix to the reinforcement. This property is mainly governed by the quality of the fibre / matrix adhesion as well as the aspect ratio of the fibre reinforcement [18].

This chapter is devoted to interfaces in composite materials reinforced by flax fibres. First, the structure and organization of a flax stem and a flax fibre will be presented, then the influence of these constitutive elements on the mechanical and thermal behaviour of the fibre will be described. An analysis of the surface of flax fibres, together with the adherence capacity of the fibre with different polymers will follow; the influence of different treatments and the characterization of adherence will also be described. Finally, at the composite scale, the influence of the dispersion of the reinforcement, the presence of defects and the choice of manufacturing route will be discussed.

\section{Analysis of the structure of a flax stem}

\subsection{Organization of a stem}

The fibres within a stem are supporting elements (they reinforce the stem) located around the exterior (figure 1) and assembled in groups in the form of bundles (figure 1), (about 40 bundles of 30 fibres). The mean diameter of a flax fibre is between 15 and $20 \mu \mathrm{m}$ and its length is between 5 and $80 \mathrm{~mm}$. An individual flax plant produces 15000 to 20000 fibres, yielding $0.3-$ $0.5 \mathrm{~g}$ dry fibres.

Examination of the structure of a flax stem provides much information. The stem has the structure of a composite material reinforced by continuous vessels (wood part) and discontinuous fibres (both in the cortex and in the wood). The wind subjects the plant to flexural and torsion loads. A bending moment results in tensile and compression strains in the stem. Behaviour in 
compression is the weak point of plant support elements. The presence of cohesive bundles of fibres, regularly distributed around the outside of the stem (figure 1), limits the risk of microbuckling in compression zones. Load transfer between fibres is performed by shared lamellae between fibres. In order to extract the fibres it will be necessary to damage these lamellae during the retting and scutching operations (see paragraph 2.3).

In order to use bio-mimetics it is interesting to understand the nature of the elements which provide this good cohesion (efficient interfaces) to the fibre bundles in the plant. This will be described in the next section.

\subsection{Role of the cell junctions in the fibre cohesion within a bundle}

In the stem, fibres tied together via their pectic junctions within a bundle structure consist of a first example/scale of composite material [figure 1]. There, the stress is transferred to the reinforcing fibres through their junctions, taken as matrix pectic-polymers. These junctions made of two main types of pectins, homogalacturonan and rhamnogalacturonan [19], are present in two morphological domains : the middle lamella between the primary cell-walls of two neighbouring fibres and the tri-cellular junctions in the corner between three fibres.

The pectic composition of fibre junctions varies within space and time dimensions during the stem growth, being adapted to the differentiation stage of the fibres (elongation, expansion, cellwall thickening). The junction remodelling might be enzyme catalyzed (for example the deesterication of pectins and the pectin cross-linking) or happen by apposition of newly synthesized pectic-polysaccharides. The strength of the junctions generally increases during the expansion and thickening of the fibres but the molecular mechanisms depend on the culture environment, considered as usual with regular sun / rain alternation or as abiotic stress in the 
case of drought [20] or high level of pollution [21]. In the former case, homogalacturonans are de-esterified, which increases their affinity for calcium ions, leading to strong calcium bridges. Moreover the rhamnogalacturonans, especially in the middle lamella, react chemically with those of the primary cell-wall (Figure 2). In addition, during a stress event, phenolics might be polymerized as lignin points throughout the junctions [22].

Prospective questions deal with the homogeneity / heterogeneity of the cohesion strength not only in the two domains of the fibre junctions but also within a bundle, since the differentiation of fibres occurs centripetally. Also, for the facilitation of the fibre extraction from the stem, questions concern the cohesion strength at the boundaries between fibre bundles and the neighbouring tissues, cortical ones, on one side, and phloem, on the other (see next paragraphs). Transmission electronic microscopy analyses coupled with immunocyto gold-labelling indicate similar pectic components in the different domains but with different proportions and linkages (data mainly collected at the University of Rouen, France). Local mechanical data are being collected using nano-indentation approaches [23].

\subsection{Impact of retting on the cohesion between fibres}

Retting - namely dew retting in Northern Europe - consists of enzyme-catalyzed degradation of cell junctions and cell walls thanks to the combined action of moisture and heat [24]. Retting may be divided into two spatio-temporal steps. First, the epidermis and cortical tissues of the stem layered on the soil are colonized by fungi which release several enzymes that degrade pectins and more generally polysaccharides [25, 26]. As a result, epidermis and cortical parenchyma are partly degraded and the fibre bundles split [27]. Calcium pectates are considered to be retting resistant and are the limiting factor of retting [28]. In a second step, the fungi 
colonize the fibre bundles where the complex pectins present in the fibre junctions might be partly degraded $[29,30]$. Such a two-step retting facilitates the fibre decortication $[31,32]$. On the other hand, if continuous rains happen at this latter retting-stage and do not allow the harvest, then the fungi continue their development within the elementary fibres, initiating rotting. Indeed, the fungi undergo the degradation of the cellulose microfibrils in the successive cell-wall layers, due to the secretion of glucanase and cellulose enzymes [33]. This step is called over-retting. For practical and economical reasons, it is hardly possible to harvest and store wet flax straw [34] because of mold development during storage. Therefore retting is a critical agricultural process, determining the state of division of the bundle and the surface quality of the so-called technical fibres.

There are alternative methods to field dew-retting. Water retting is no longer an option due to water pollution by substances created by the anaerobic degradation of the plants. On the other hand, various enzyme retting processes have been developed [35-37] being quite efficient to avoid fibre rotting and maintain the mechanical properties of the elementary fibres; still, these alternative methods are not used because they are considered costly.

Some of the variation in the degree of retting can be reduced 1) by modifying the subsequent mechanical treatments of the straw (breaking, scutching and hackling), which separate the bast fibres from the woody core and 2) by degumming treatments during the wet spinning-process [38]. At the end, partially degraded bundles constitute the so-called technical fibres that are a mixture of a certain number of fibres (1 to 10) with loose cohesion between each other and the debris of cortical tissues.

\section{4 impact of retting on the physicochemical properties of technical and elementary fibres}


Physicochemical properties of technical fibres obviously depend on the retting step, scutching/hackling, and degumming (possibly surfacting) treatments. Chemical composition, swelling, vapour water sorption, surface properties, thermal stability have been largely reported to vary with the degree of retting and the subsequent mechanical and/or chemical treatments [32, 36, 39-41]. Also, the mechanical properties of single fibres are influenced by the degree of retting [36, 42]. Higher retting degree can result in higher Young's modulus and strength [36, 41, 42]. There is little variation in the failure strains. The scatter in values tends to decrease with increasing retting degree [42]. Conversely, over-retting as well as most of the chemical treatments negatively impact the tensile properties [40, 43].

All these properties together with the surface aspect (clean or presence of cortical residues, smooth or with large roughness) and the morphology (ratio of perimeter to surface) would impact the establishment of interface when manufactured with polymers (see paragraphs 4 and 5).

\section{Composition and structure of a single flax fibre.}

The mechanical properties of composites depend on both the characteristics of reinforcing fibres and the quality of the interface with the matrix resin. This review is focused on the role of interfaces and thus on the surface condition of the fibres; this will depend not only on the agroindustrial processes of extraction of technical fibres (see above) but also on the development history of the fibre within the stem of the plant. In the following section, the study of the development of the fibre describes not only the composition of the inter-fibre connections and the primary cell walls which constitute the surface state of the fibre but also the synthesis of the secondary wall (in particular the S2 layer). This is a model for the construction of a composite 
material, with a matrix and a reinforcement of similar composition and optimized interfaces, in terms of quality and quantity, resulting in excellent properties of the fibre material.

\subsection{Development of fibres}

Throughout the growth of the plant, fibres are formed around the outside in a coordinated manner with the criblo-vascular bundles (conducting tissues) of the stem; this occurs in four distinct steps 1) fibre-cell multiplication at the top of the stem [44], 2) elongation in the 3-5 $\mathrm{cm}$ of the stem top, 3) fibre expansion and thickening of the walls below the snap point, a zone defined in [45] where the stiffness of the stem increases significantly and 4) structuring of the wall leading in some cases to a reduction in the fibre diameter [29, 46]; this occurs after the seed formation, in certain varieties and/or as a function of the environment.

During the second phase of elongation, which lasts 3 to 5 days per fibre [47], the cell extends by around 5 to $20 \mathrm{~mm}$ per day [48] to reach up to $100 \mathrm{~mm}$ [49] mainly by the so-called intrusive growth. This enables the fibres to penetrate through the shared lamellae between neighbouring cells [48]; if the intrusive elongation starts with a tip growth leading to a spindlelike shape of the fibre, the main part of elongation occurs by diffuse symplasmic growth along the entire cell $[47,48,50]$. This means that the final length of the cells is obtained not by classical division (multiplication of the chromosomes and cellular division cellulaire by construction of a septum then laying down a cell wall on either side of the septum) but uniquely by multiplication of the nuclei and then by cellular elongation. At the end, each fibre can possess several tens of nuclei [48].

This extension of the fibres stops progressively at the snap point [49]. The fibre is then, as all cells, bounded along its whole length by a continuous primary cell wall, whose cellulose 
meso*-fibrils are aligned parallel to the growth direction. The thickness of primary wall is between 200 and $500 \mathrm{~nm}$ [51] and it is usually made up of one third pectins, one third hemicelluloses (see the definition below) and one third cellulose [52].

The interfibre junctions are acidified and reinforced by calcium links and by the establishment of covalent bonds between RG-I of the shared lamella and of the primary cell wall (see above). The surface of the fibres after retting is particularly rich in these RGI whose linear density of negative charges is on average $1 \mathrm{~nm}^{-1}$.

The third phase corresponds to the synthesis of a secondary cell wall which, little by little and layer by layer fills the cellulosic fibres of the flax. The study of the synthesis of this first layer illustrates the strategy of fibres in producing a composite material.

* The terminology used to describe cell wall reinforcement geometry is rather confused. Based on a diameter between 2 and $4 \mathrm{~nm}$, Burgert et al. [53], Altaner et Jarvis [54] et Peterlin et Ingram [55] use the term cellulose microfibrils whereas Fraztl [56] talk of cellulose fibrils. The term macrofibril is used for diameters between 100 and $200 \mathrm{~nm}$ by Altaner and Jarvis [54] and Peterlin and Ingram [55]. However Bos et al. [57], in their work on the compression behaviour of fibres use the term meso-fibrils (assembly of microfibrils) for elements of dimensions around 200nm. We will use this latter denomination here. 


\subsection{S1 to S3 layers in the secondary wall}

Gorshova et al. [45] have shown that the initiation of the first deposit is preceded by a strong secretion of non cellulosic polysaccharides (ncps) and glycoproteins rich in galactose and with a high molecular weight $(>1 \mathrm{M})$. It has been proposed that the environment of such an extracellular matrix in which the cellulose mesofibrils are excreted, plays an important role in determining the final size and orientation of the mesofibrils [46]. The use in transmission electron microscopy of a gold-labelled cellobiohydrolase, enzyme specific to crystalline cellulose, together with Patag's reactive, a marker of the non-crystalline cellulose, enabled His et al. [58] to show that this first layer gradually becomes more structured and bound to the primary cell-wall. The cellulose of the first layer appears highly crystalline at the moment when the second layer is deposed. Thus this first layer progressively brings a certain stiffness to the fibre [59]. The molecular processes involved in this stiffening are reviewed in $[46,60]$. The enzymes secreted at the same time as the non-cellulosic polymers catalyze the remodelling of the latter, allowing the cellulosic nanofibrils (section 2 to $4 \mathrm{~nm}$ for around 36 molecules) to group and form microfibrils (section 20-40 nm). These microfibrils are surfaced by the hemicelluloses and incrusted within a remodeled pectin matrix.

Whatever the process, the formation of mesofibrils and their association with the noncellulosic polymers is complex, resulting in multilayer fibre-reinforced composite-wall structures composed of three main layers $\mathrm{S} 1(\sim 0.5-2 \mu \mathrm{m}), \mathrm{S} 2(\sim 5-10 \mu \mathrm{m})$ and $\mathrm{S} 3(\sim 0.5-1 \mu \mathrm{m})$. S2, the main structural layer, is responsible for the majority of the mechanical performance and the physical properties of the fibre (Figure 2). S3 surrounds a cavity known as a lumen whose volume, inversely proportional to that of the secondary cell walls. 


\subsection{Influence of the microstructure on the tensile behaviour of a fibre}

As described above (Figure 2), the stiffness of the secondary cell-walls is the result of the presence of highly oriented cellulose mesofibrils within the S2 layer. These mesofibrils represent more than $80 \%$ of the weight and with the non-cellulosic polysaccharides (ncps) in which they are inserted, they form a high performance composite. Different theories, based on the work of mechanical engineers or biologists, enable the arrangements of the different cell wall constituents to be explained.

Hearle [61] showed that the cellulose mesofibrils are closely linked to the amorphous polysaccharides and form a non-covalent network with the hemicelluloses (principally glucomananes and galactanes according to Gorshkova \& Morvan [62]). The hemicelluloses are bonded to the cellulose mesofibrils by hydrogen bonds which, on account of their large number, create strong associations with the cellulose. Part of the hemicelluloses can form inter-cellulose bridges and/or entanglements (and untangle) with the pectic matrix. Beyond a certain shear stress threshold this network can fail due to breakage of the hydrogen bonds between the constituents.

Other studies on wood have revealed a stick-slip (Velcro®) mechanism in the secondary cell walls [54, 63, 64]. According to Burgert [65] and Keckes et al. [63], the Velcro® mechanism is partly reversible after loading and other hydrogen bonds between cellulose and hemicellulose will be built elsewhere. Altaner and Jarvis [54] propose a slightly different model in which, in addition to hydrogen bonds with cellulose, the hemicellulose chains can make bridges or loops with cellulose mesofibrils.

Comparative work on the fibre structure of different varieties of flax [66] have shown stiffness differences related to cellulose content in the cell walls; the varieties with the highest cellulose content were represented with cellulose fibrils the closest together and a less well- 
developed matrix between fibrils. The bridges between glucomananes chains have been proposed to explain the stiffness differences observed [67].

In flax fibres other components such as arabinogalactan proteins rich in glycine (GRP), and $\beta-1-4$ galactans have also been proposed to play the role of «hemicelluloses», i.e. of compatibilisers between the celluloses mesofibrils and the pectic chains (RG-I) to which they are linked, representing a true interphase between the matrix and the cellulose and guaranteeing the cohesion of the system $[46,67,68]$. This configuration can be reinforced by the presence of homogalacturonans which will consolidate the interphase between the galactans and the pectic matrix $[66,69]$. This analysis was based on models of in vitro interactions studied by Zykwinska et al. [70] and primary cell wall models elaborated by Cosgrove [71].

A schematic synthesis of the structure of the S2 cell wall is proposed in figure 2. Recent studies $[12,15]$ have shown the prime importance of the organization of the plant cell-wall components and their structure in the mechanical performance. More than the quantity of cellulose, which is present in sufficient amounts to ensure good performance, the ratio between the structural polysaccharides and matrix within the S2 layer present a high correlation with the stiffness of flax fibres.

In conclusion, within the cellulosic flax fibres, the cellulose mesofibrils (> 80\%), arranged in spirals [72] within an amorphous polysaccharide matrix made up of hemicelluloses and pectins rich in galactose [68], and oriented at an angle of around 8-10 ${ }^{\circ}$ [73] with respect to the fibre axis, make up a composite material structure, with many levels of interfaces. The multilayer growth of this material which involves several remodeling mechanisms, results in good mechanical behaviour of the individual fibres and could provide a source of inspiration for developing biomaterial composites. 
Prospective questions deal with the detailed composition of the composite throughout the successive layers and subsequently with the strength of their interfaces.

\subsection{Influence of the wall composition on the thermal behaviour of fibres}

On account of the nature of the constituents of the cell walls, the temperature, and as a consequence, the water content, will have a strong influence on the mechanical properties of plant fibres. From 1963, Hearle [61] underlined the importance of water, proposing that the Young's modulus of plant fibres will decrease as water content increases; water will not penetrate into the crystalline zones, and he attributed the drop in properties to a modification of inter-fibrillar constituents. According to Altaner et al. [54], water enters the polysaccharide network and causes the cellulose fibrils to separate. Thus the water acts to plasticize the cell walls [74] which will transform the polysaccharides, and in particular the water-soluble glycans, into a quasi-fluid gel. It is mainly the carboxylic groups of pectins which are responsible for the water absorption by the fibres, the water content will therefore be conditioned by the degree of fibre retting.

Baley et al. [75] have shown that water causes loss of interactions (and of hydrogen bonds) between the cell wall components. Water plasticizing the non crystalline polysaccharides of the cell walls, its absorption by the fibres generally leads to an increase in their failure strain. After heating for $14 \mathrm{~h}$ at $105^{\circ} \mathrm{C}$ [76], it has been shown that, in spite of the retention of part of the water linked to the polysaccharide constituents of the S2 layer, the tensile strength of the fibres is strongly affected by this drying cycle. In addition, early appearance of a damage threshold was noted on modulus versus strain plots. The water removal embrittles the constituents [75], and especially the hydrated gel network formed by the polysaccharide matrix [77]. These phenomena 
will affect the interactions between mesofibrils and pectin matrix.

It is possible to examine the fibre thermal-behaviour using thermo-gravimetric analysis (TGA). This was studied by Van de Velde et al. [41] who showed that the different weight losses can be related to loss of water, to degradation of the cellulose and of its non-cellulosic components (mainly hemicelluloses and pectins). Gassan et Bledzki [78] have shown that the mechanical properties of jute and flax fibres start to be affected by the temperature at around $170^{\circ} \mathrm{C}$. Placet [79], performed dynamic mechanical analyses (DMA) on hemp fibre bundles at different temperatures. A drop in storage modulus and an increase in loss factor were revealed between 20 and $200^{\circ} \mathrm{C}$. These changes may be caused by transition phenomena within the polymers which make up the plant cell walls (cellulose, hemicelluloses, pectins); their rheological behaviour is controlled by the intrinsic responses of these three main constituents. Bundles have also been subjected to cycling for several hours under isothermal conditions. An accommodation phenomenon, revealed as an increase in stiffness, is noted. In addition, the fatigue behaviour is strongly affected, bundles can support more than 60000 cycles at $20^{\circ} \mathrm{C}$ compared to only 6500 at $220^{\circ} \mathrm{C}$. The accommodation phenomenon may be explained by the progressive decrease in the microfibril angle observed by different authors by X-ray diffraction during tensile tests $[63,65]$.

In general, an increase in temperature is therefore harmful to the mechanical performance of plant fibres, causing a drop in short and long term properties. Thermal treatments inspired by wood technology such as Duralin ${ }^{\circledR}$ can be applied to plant fibres [80] in order to reduce their hydrophilic behaviour and to improve thermal resistance. 


\section{Surface of a flax fibre}

The surface of a material is generally composed of the first planes of atoms which interact with the neighbouring environment. For the case of flax fibres the multi-layer structure [81] implies that the outer layer is the fibre surface and corresponds to the primary cell wall whose thickness varies between 200 and $500 \mathrm{~nm}$ [57] with more and less residues of junctions and even of cortical residues. This latter has been described in detail in section 3-1 and its composition is heterogeneous as it includes cellulose, hemicelluloses and pectins. The composition of the surface of fibres will also vary according to the degree of retting [57, 82, 83]. Certain surface residues have a strong influence on the surface roughness (Figure 3) and the specific surface [84]. Thus, Le Duigou et al. [85] used Atomic Force Microscopy (AFM) to evaluate fibres correctly retted (Hermès variety), and measured a roughness varying from 10.8 to $14.3 \mathrm{~nm}$ (compared to a few $\mathrm{nm}$ for a glass fibre) over an area of $1 \mu \mathrm{m}^{2}$. When a larger surface area is analyzed $\left(25 \mu \mathrm{m}^{2}\right)$, the roughness can reach $35 \mathrm{~nm}$ [86]. Cleaning in water for 72 hours or applying a thermal cycle can reduce this roughness to around $5 \mathrm{~nm}$.

These residues are generally poorly adherent to the surface of the fibre and cannot serve as mechanical anchor points for polymers. They can play an important role in energy dissipation during interface failures, but in the present case they are more likely to be zones of low cohesion and failure initiation.

Among the surface properties of flax fibres, the surface energy $\gamma_{s}$, a thermodynamic property, indicates the aptitude of the surface to create interactions (van der Waals and/or acid/base) with a matrix. Wetting of fibres by the liquid matrix, an essential step in the manufacture of composites, is mainly controlled by the surface energies of the two components. This wetting is a necessary but not sufficient condition to obtain a good fibre/matrix adherence. For plant fibres the 
heterogeneity of the surface composition, the roughness, the porosity, the adsorption of liquids, geometrical variations and the very small dimensions of samples make the characterization of surfaces with the usual techniques quite difficult (goniometer [87, 88], Wilhelmy balance [89], Washburn tube [90, 91], inverse gas chromatography [92]). Original techniques are being developed, such as AFM with a colloidal probe [93].

Surface energies, involving non-polar components (London interactions) and polar component (Debye interactions, Keesom, acid-base...) are very strongly influenced by the flax fibre surface composition. Thus, Van Hazendonk et al. [94] have shown by selective extraction, that each of the constituents (cellulose, hemicelluloses, pectins...) plays a role in the surface energy of fibres. For example, the waxes, with low surface energies (around $25 \mathrm{~mJ} / \mathrm{m}^{2}$ ) globally reduce $\gamma \mathrm{s}$ whereas the pectins and hemicelluloses show an intermediate surface energy (around $40 \mathrm{~mJ} / \mathrm{m}^{2}$ ). The surface energy of the fibre increases as a function of the cellulose proportion (around $60 \mathrm{~mJ} / \mathrm{m}^{2}$ ). These values should be treated with caution however, as the polysaccharides present on the surface of flax fibres, even if they belong to the same family (pectins for example) can show variations in composition (degree of methylesterification, degree of polymerization, degree of crystallinity) $[68,95,96]$. Thus, the application of thermodynamic wetting theory should be performed carefully [97].

In order to obtain high performance and durable composites, surface treatments can also be envisaged composites in addition to mechanical treatments during extraction of fibres (scutching, hackling). The surface treatments have been the subject of recent reviews [98-100]. These fibre treatments can be divided into three distinct categories, aiming to retain the properties of the plant cell walls but with different objectives: individualization of the fibres, cleaning and/or modification of surfaces. These different fibre treatments will not be detailed here, they are 
discussed in other chapters.

\section{Adherence between flax fibre and polymer}

\subsection{Choice of a micro-mechanics test to characterize the adherence}

There are several micro-mechanics tests available to study the shear strength of a fibre/matrix interface. The most common are : fragmentation, compression, micro-indentation, pull-out and micro-droplet debonding [101]. The method retained here is the debonding of a microdroplet of matrix from a single fibre [102] (Figure 4). This method allows the evaluation of the fibre/matrix adherence, the mechanisms of debonding and the wetting, the latter through contact angle measurement. The first step is to extract a single fibre from a bundle, then to place a microdroplet on it. The latter is quite straightforward for a thermoset matrix which is liquid at room temperature. For a thermoplastic which is solid at room temperature the simplest approach is to use a thin polymer thread, to make a knot with it around the fibre, then to apply a heating cycle to melt the polymer and form a droplet. Before characterization, each specimen is examined using an optical microscope in order to measure the geometry (fibre diameter, droplet diameter, bonded length), to check the symmetry of the droplet and the absence of defects. In order for the debonding force to be proportional to the bonded area the bonded length should be short (less than $250 \mu \mathrm{m}$ ) [103]. In reality, a length shorter than $150 \mu \mathrm{m}$ is generally used in order to reduce the likelihood of fibre breakage, particularly during a long thermal treatment. When the specimens are placed in the test machine, the knives on the micrometric plateau (figure 4) are adjusted under a microscope. Then the debonding of the droplets is observed by microscope and the force and displacement are recorded continuously. The tensile loading rate is $0.1 \mathrm{~mm} / \mathrm{min}$. Various authors have analyzed the stress distribution in a microdroplet by finite element 
methods, [101, 104-107], by photo-elasticity [101] and by Raman spectroscopy [108, 109]. These studies have shown that the loading is complex (the shear stresses are not constant along the fibre/matrix interface) and that residual thermal stresses are not negligible. The simplest analysis of these tests is based on the determination of an apparent interfacial shear stress (IFSS). In this case a uniform shear stress distribution along the bonded length is assumed. This simplifying assumption allows comparisons to be made between different fibre/matrix combinations.

\subsection{Flax/polymer bonding. Experimental examples.}

The interfacial strength between plant fibres and polymers is often considered in the literature to be poor, many authors considering that adherence of a hydrophilic fibre to a hydrophobic polymer cannot be good. This section presents interface test results obtained on flax and glass fibres with three different polymer matrices (Table 1). Table 1 shows that, for the three polymers studied (Poly(L)-lactid acid (PLLA), epoxy and unsaturated polyester), the adherence is of the same order of magnitude for glass and flax fibres. These values are high, flax/polymer adherence is not a weakness for these materials.

Partial peeling of internal layers of the fibre (Figure 4) have been observed in some particular cases: after drying of fibres or after aging in water [85]. This type of damage can be explained by an evolution of the fibre microstructure. This peeling also affects the post-debonding friction behaviour, particularly for flax/PLA [85]. Thus for a composite material reinforced by flax fibres even though the fibre/matrix interface is of prime importance it is also absolutely essential to consider the internal interfaces between layers within the fibres. 
Table 1. Examples of apparent interfacial shear strengths (IFSS) determined by micro-droplet debonding.

\begin{tabular}{|c|c|c|}
\hline Material & IFSS (MPa) & Reference \\
\hline PLLA (Naturworks®)/Flax & $16.4 \pm 3.8$ & {$[85]$} \\
\hline PLLA (Biomer@)/Flax & $15.3 \pm 3.3$ & {$[110]$} \\
\hline PLA/Glass & $7.5 \pm 2.3$ & {$[85]$} \\
\hline Epoxy/Flax & $22.7 \pm 0.8$ & {$[87]$} \\
\hline Epoxy/glass & $29.3 \pm 2.4$ & {$[111]$} \\
\hline Unsaturated polyester/Flax & $14.2 \pm 0.4$ & {$[87]$} \\
\hline Unsaturated polyester/Glass & $16.1 \pm 0.5$ & {$[87]$} \\
\hline
\end{tabular}

\subsection{Influence of different treatments (Flax/PLA)}

The treatments presented in this section were applied in order to understand the role of the fibre/matrix interface. The apparent interfacial shear stress (IFSS) of a flax/PLA system is controlled by the many interactions between the fibre surface and the matrix, such as van der Waals forces, Acid/ Base, and hydration $[112,113]$. The residual stresses induced during a manufacturing cycle arising from the differences in thermal expansion coefficients and by changes in crystallinity will affect the IFSS [85]. 
Table 2. Examples of apparent interfacial shear stresses of PLA/flax systems determined by microdroplet debonding for different treatments. applied to the fibre or composite.

\begin{tabular}{|c|c|c|c|}
\hline Material & Treatment & IFSS (MPa) & Ref \\
\hline \multirow{4}{*}{$\begin{array}{c}\text { Treatments on } \\
\text { fibres }\end{array}$} & Untreated fibres & $15.3 \pm 3.3 ; 16.4 \pm 3.8$ & Table 1 \\
\cline { 2 - 3 } & Water (72h) & $18.8 \pm 3.2$ & \multirow{2}{*}{ [85] } \\
\cline { 2 - 3 } & Heat $\left(105^{\circ} \mathrm{C}-14 \mathrm{~h}\right)$ & $13.6 \pm 3.3$ & \\
\cline { 2 - 3 } & Release agent & $4.8 \pm 1.3$ & \multirow{2}{*}{ [110] } \\
\hline \multirow{3}{*}{$\begin{array}{c}\text { Treatments on } \\
\text { composites }\end{array}$} & Air cooling & $15.3 \pm 3.3$ & \multicolumn{1}{|c}{} \\
\cline { 2 - 3 } & $10^{\circ} \mathrm{C} /$ min cooling & $18.2 \pm 1.8$ & \\
\cline { 2 - 3 } & $1^{\circ} \mathrm{C} /$ min cooling & $22.2 \pm 3.4$ & \\
\cline { 2 - 3 } & Annealing $\left(50^{\circ} \mathrm{C}-72 \mathrm{~h}\right)$ & $9.9 \pm 1.5$ & \\
\hline
\end{tabular}

Cleaning the fibre surface with water will dissolve certain components [11] and together with the reduced surface roughness [85] results in a small increase in IFSS (Table 2). High roughness of fibres is therefore not an explanation for good interfacial properties, as has sometimes been proposed. An increase in the amount of peeling during debonding is noted after this treatment. The drying cycle at $105^{\circ} \mathrm{C}$ implies a loss of water of around $6 \%$ and a reduction in surface roughness. Here the IFSS drops by around 20\% (Table 2). The migration of low molecular weight components, the modification of these components and surface porosity may explain this change [114-118]. Once again an increase in the amount of fibre peeling is noted. Adding a debonding agent to the fibre surface reduces the IFSS as expected [85].

The cooling rate of PLA after moulding plays an important role: the slower the cooling, the higher the IFSS. This change may be caused by residual stresses but the matrix morphology 
close to the fibre also changes. An annealing step below the glass transition temperature allows a relaxation of residual stresses, underlining their role in interfacial adherence.

\section{Flax/polymer interfaces and composite materials}

\subsection{Damage mechanisms}

In a composite material reinforced by glass fibres (or PAN carbon), observation of fracture surfaces reveals four damage mechanisms: axial fibre breakage, matrix and fibre/matrix interface cracking, and fibre debonding. For a polymer reinforced by flax fibres additional mechanisms can be observed, fibre breakage in the transverse direction [119], in shear between and within the secondary cell walls [76]. Also, if a polymer is reinforced by fibre bundles then cracks can also appear in the shared lamella [119]. Stress concentrations, related to the presence of kink bands [120] and modifying the load transfer between fibres and matrix, can also appear in the composite. These defects can develop when the fibrillar structure is loaded in compression [10], for example during operations to separate the fibres from the plant.

\subsection{Influence of fibre separation on mechanical properties of composites}

Within the plant, the fibres are grouped around the outside of the stem in the form of bundles (Figure 1). The latter are made up of tens of fibres linked together by shared lamella. In spite of the retting and mechanical separation operations the cohesive nature of these bundles results in a certain amount persisting through to the final composite component. The flow conditions during manufacture can also result in the formation of clusters of fibres. As a result the bundles may cause a significant drop in the reinforcement aspect ratio, and hence a drop in their reinforcing capacity. 
Bos [121] has shown how flax fibre bundles can affect the mechanical properties of composites. Rask et al. [122] studied the damages processes of PP/flax UD by using X-ray diffraction; they concluded that well separated fibres are recommended for composite reinforcements. Andersons and Joffe [123] enounced similar conclusions by demonstrating that a probabilistic model, assuming perfect separation and regular spacing of fibres, yields an upper limit of strength for UD flax composites. The influence of the dispersion of single fibres on the mechanical properties of flax/ polypropylene composites has also been shown [17]. Morphological analyses highlighted the importance of a hackling step for fibre dispersion; this process reduces the number of bundles in the final composite. Fibres subjected to combing have been used to manufacture composites with a separated fibre content similar to that found with glass fibres.

The study of damage in polypropylene composites reinforced by injected flax fibres [124] has shown, as for traditional composites, a significant skin/core effect $[125,126]$. Shearing effects close to the mould result in high orientation of the fibres in the flow direction in these regions, whereas in the core, as a result of divergent flow and lower shear, the orientation is more isotropic. This results in more fibre bundles in the core which can cause premature failure in this region and a drop in composite strength and failure strain. Tensile tests performed inside a scanning electron microscope (Figure 5) confirmed this effect, showing crack propagation within clusters of fibres.

Thus fibre clusters and bundles promote damage initiation and fracture propagation ; in order to improve composite quality and performance it is necessary to improve the separation and dispersion of fibres by optimizing not only the extraction procedures but also the manufacturing conditions. 


\subsection{Choice of manufacturing process}

Composites materials reinforced by natural fibres can be manufactured using classic processes; references $[8,127]$ show examples for different fibre/matrix combinations. During processing the reinforcing fibres are subjected to high temperatures, which affect their properties. Van de Velde et al. [41] showed that water removal and degradation of waxes occur from $120^{\circ} \mathrm{C}$, while pectin degradation starts around $180^{\circ} \mathrm{C}$. For Gassan et al. [78], the degradation of flax fibres, and a reduction in their toughness, appears from $170^{\circ} \mathrm{C}$ due to depolymerization and chain breakage. Nanoindentation tests performed in-situ on flax fibre cross-sections before and after manufacture [39] revealed a strong drop in fibre stiffness after injection moulding. A transformation by film stacking was shown to be less severe for the plant walls due to lower shear levels associated with this process. Similar conclusions on process-mechanical property relationships were reached by Le Duigou et al. [7] for flax/PLA biocomposites.

Thus the use of aggressive processes involving high shear stresses has a strong influence on the fibre morphology [128], resulting in a reduction in the length and diameter of the fibres bundles. The reduction in diameters is interesting for the aspect ratio but the drop in lengths must be limited; thus high rotation speeds induce an improved fibre dispersion but lower aspect ratios. Technologies such as Buss co-mixers can be used to reduce fibre changes [129] thanks to adapted profiles and delayed fibre introduction. The residence time is an important parameter, too short a duration results in poor dispersion while long residence can favour matrix and fibre degradation [130]. Increasing the rotation speed of the extrusion screw reduces residence time but can in some cases induce drops in modulus and flexural and tensile strengths of composites [128]. Finally, the temperature of extruders and injection processes is an important parameter. A high temperature favours fibre dispersion through higher matrix fluidity [131]. However, as 
shown by $\mathrm{Li}$ et al. [132] on flax/PE composites, a compromise must be found as high temperatures can cause permanent damage to plant fibres.

\section{Conclusions}

As a result of their role as a support framework for plant stems, flax fibres have a mechanical function in nature. A first interface is observed when they are assembled in bundles with shared lamella. These interfaces are damaged during retting. This step has therefore a direct influence on the surface properties (composition, roughness...) and on the volume (composition, mechanical properties...) of the fibres. The mechanical treatments which follow (scutching, hackling) do not result in a complete separation of the fibres. Additional operations can be performed either to separate the fibres more completely, to clean the surface or to add functions in order to optimize the interfacial area and to homogenize the composite material. A second interface can be defined at this scale.

The flax fibre itself is a multilayer structure, made up of a primary wall on a secondary wall reinforced by cellulose mesofibrils revealing another levels of interface. The S2 layer of the secondary wall controls the mechanical properties of the fibres at a nanometric level, the load transfer between fibrils being ensured by constituents acting as an interphase. This is the final interface zone which affects composite properties.

Water also plays a key role, acting as a plasticizer. However, as composite manufacture requires a thermal cycle this causes loss of water, so the manufacturing process can embrittle the material. This chapter presents a detailed description of the flax fibre structure, their growth and their reinforcement capacity when combined with polymers. The existence of interfacial zones within cell walls, between fibres within bundles and between fibres and matrix polymers reveals the 
complexity of the damage mechanisms which can occur in natural fibre composites. This requires a different approach to material design compared to conventional composites, as the regions which are most sensitive to damage are not necessarily the fibre/matrix interfaces but may be within the fibres themselves.

\section{Bibliography}

1. Baley, C., Fibres naturelles de renfort pour matériaux composites, in techniques de l'Ingénieur. 2013.

2. Le Duigou, A., P. Davies, and C. Baley, Environmental impact analysis of the production of flax fibres to be used as composite material reinforcement. J. biobased. mater.bioenerg., 2011. 5: p. 1-13.

3. Le Duigou, A., P. Davies, and C. Baley, Replacement of glass/unsaturated polyester composites by flax/PLLA biocomposites: Is it justified? J. biobased mater. bioenerg., 2012. 5(4): p. 466-482.

4. Le Duigou, A., J.-M. Deux, P. Davies, and C. Baley, PLLA/Flax Mat/Balsa Bio-Sandwich Environmental Impact and Simplified Life Cycle Analysis, in Applied Composite Materials. 2012, Springer Netherlands. p. $1-16$.

5. Bourmaud, A. and C. Baley, Investigations on the recycling of hemp and sisal fibre reinforced polypropylene composites. Polymer Degradation and Stability, 2007. 92( 6): p. 1034-1045.

6. Bourmaud, A. and C. Baley, Rigidity analysis of polypropylene/vegetal fibre composites after recycling. Polymer Degradation and Stability, 2009. 94(3): p. 297-305.

7. Le Duigou, A., I. Pillin, A. Bourmaud, P. Davies, and C. Baley, Effect of recycling on mechanical behaviour of biocompostable flax/poly(l-lactide) composites. Composites Part A: Applied Science and Manufacturing, 2008. 39(9): p. 1471-1478.

8. Baley, C., Y. Grohens, and I. Pillin, Etat de l'art sur les matériaux composites biodégradables. Revue des Composites et des Matériaux Avancés, 2005. 14(2): p. 135-166.

9. Bodros, E., I. Pillin, N. Montrelay, and C. Baley, Could biopolymers reinforced by randomly scattered flax fibre be used in structural applications? Composites Science and Technology, 2007. 67(3-4): p. 462-470.

10. Baley, C., Analysis of the flax fibres tensile behaviour and analysis of the tensile stiffness increase. Composites Part A: Applied Science and Manufacturing, 2002. 33(7): p. 939-948.

11. Bourmaud, A., C. Morvan, and C. Baley, Importance of fiber preparation to optimize the surface and mechanical properties of unitary flax fiber. Industrial Crops and Products, 2010. 32(3): p. 662-667.

12. Bourmaud, A., C. Morvan, A. Bouali, V. Placet, P. Perré, and C. Baley, Relationships between microfibrillar angle, mechanical properties and biochemical composition of flax fibers. Industrial Crops and Products, 2013. 44(0): p. 343-351.

13. Charlet, K., C. Baley, C. Morvan, J.P. Jernot, M. Gomina, and J. Bréard, Characteristics of Hermès flax fibres as a function of their location in the stem and properties of the derived unidirectional composites. Composites Part A: Applied Science and Manufacturing, 2007. 38(8): p. 1912-1921.

14. Charlet, K., J.P. Jernot, M. Gomina, J. Bréard, C. Morvan, and C. Baley, Influence of an Agatha flax fibre location in a stem on its mechanical, chemical and morphological properties. Composites Science and Technology, 2009. 69(9): p. 1399-1403.

15. Lefeuvre, A., A. Bourmaud, L. Lebrun, C. Morvan, and C. Baley, A study of the yearly reproducibility of flax fiber tensile properties. Industrial Crops and Products, 2013. 50(0): p. 400-407.

16. Pillin, I., A. Kervoelen, A. Bourmaud, J. Goimard, N. Montrelay, and C. Baley, Could oleaginous flax fibers be used as reinforcement for polymers? Industrial Crops and Products, 2011. 34(3): p. 1556-1563. 
17. Coroller, G., A. Lefeuvre, A. Le Duigou, A. Bourmaud, G. Ausias, T. Gaudry, and C. Baley, Effect of flax fibres individualisation on tensile failure of flax/epoxy unidirectional. Composites Part A: Applied Science and Manufacturing, 2013.

18. Kelly, A. and W.R. Tyson, Tensile properties of fibre-reinforced metals: Copper/tungsten and copper/molybdenum. Journal of the Mechanics and Physics of Solids, 1965. 13(6): p. 329-338.

19. Andème-Onzighi, C., R. Girault, I. His, C. Morvan, and A. Driouich, Immunocytochemical characterization of early-developing flax fiber cell walls. Protoplasma, 2000. 213(3-4): p. 235-245.

20. Chemikosova, S., N. Pavlencheva, O. Gur'yanov, and T. Gorshkova, The effect of soil drought on the phloem fiber development in long-fiber flax. Russ J Plant Physiol, 2006. 53: p. 656-662.

21. Douchiche, O., A. Driouich, and C. Morvan, Spatial regulation of cell-wall structure in response to heavy metal stress: cadmium-induced alteration of the methylesterification pattern of homogalacturonan. Annals of Botany, 2010. 105: p. 481-491.

22. Day, A., K. Ruel, G. Neutelings, D. Crônier, H. David, S. Hawkins, and B. Chabbert, Lignification in the flax stem: evidence for an unusual lignin in bast fibers. Planta, 2005. 222: p. 234-245.

23. Bourmaud, A. and C. Baley, Nanoindentation contribution to mechanical characterization of vegetal fibers. Composite Part B, 2012. 43(7): p. 2861-2866.

24. Brown, A.E., H.S.S. Sharma, and D.L.R. Black, Relationship between pectin content of stems of flax cultivars, fungal cell wall-degrading enzymes and pre-harvest retting. Annals of Applied Biology, 1986. 109(2): p. 345-351.

25. De Franca, F., J. Rosemberg, and A. De Jesus, Retting of flax by Aspergillus niger. Applied Microbiology, 1969. 17: p. 7-9.

26. Meijer, W.J.M., N. Vertregt, B. Rutgers, and M. van de Waart, The pectin content as a measure of the retting and rettability of flax. Industrial Crops and Products, 1995. 4(4): p. 273-284.

27. Akin, D.E., G.R. Gamble, W.H. Morrison Iii, L.L. Rigsby, and R.B. Dodd, Chemical and Structural Analysis of Fibre and Core Tissues from Flax. Journal of the Science of Food and Agriculture, 1996. 72(2): p. $155-165$.

28. Sharma, H.S.S., Chemical retting of flax using chelating compounds. Annals of Applied Biology, 1988. 113(1): p. 159-165.

29. Andème-Onzighi, C., R. Girault, I. His, C. Morvan, and A. Driouich, Immunocytochemical characterization of early-developing flax fiber cells. Protoplasma, 2000. 213: p. 235-245.

30. Jauneau, A., C. Morvan, F. Lefebvre, M. Demarty, C. Ripoll, and M. Thellier, Differential extractability of calcium and pectic substances in different wall regions of epicotyl cells in young flax plants. Journal of Histochemistry and Cytochemistry, 1992. 40: p. 1183-1189.

31. Kessler, R.W., U. Becker, R. Kohler, and B. Goth, Steam explosion of flax - a superior technique for upgrading fibre value. Biomass and Bioenergy, 1998. 14(3): p. 237-249.

32. Sharma, H.S.S., G. Faughey, and G. Lyons, Comparison of physical, chemical, and thermal characteristics of water-, dew-, and enzyme-retted flax fibers. Journal of Applied Polymer Science, 1999. 74(1): p. 139143.

33. Brown, A.E. and H.S.S. Sharma, Spoilage of flax straw by Ceraceomyces sublaevis. Transactions of the British Mycological Society, 1986. 86(1): p. 173-175.

34. Pallesen, B.E., The quality of combine-harvested fibre flax for industrials purposes depends on the degree of retting. Industrial Crops and Products, 1996. 5(1): p. 65-78.

35. Akin, D.E., Linen Most Useful: Perspectives on Structure, Chemistry, and Enzymes for Retting Flax. ISRN Biotechnology, 2013. 2013: p. 23.

36. Alix, S., L. Lebrun, S. Marais, E. Philippe, A. Bourmaud, C. Baley, and C. Morvan, Pectinase treatments on technical fibres of flax: Effects on water sorption and mechanical properties. Carbohydrate Polymers, 2012. 87(1): p. 177-185.

37. Jauneau, A., F, C. Rihouey, and C. Morvan, Les traitements biologiques du lin. Biofutur, 1997. 167: p. 3437.

38. Fausten, M., Méthodes de préparation et de qualification des fibres de lin, in Journées d'échanges FrancoAllemandes sur le lin. 1992: Rouen. 
39. Bourmaud, A. and C. Baley, Effects of thermo mechanical processing on the mechanical properties of biocomposite flax fibers evaluated by nanoindentation. Polymer Degradation and Stability, 2010. 95(9): p. 1488-1494.

40. Morvan, C., A. Jauneau, A. Flaman, J. Millet, and M. Demarty, Degradation of flax polysaccharides with purified endo-polygalacturonase. Carbohydrate Polymers, 1990. 13(2): p. 149-163.

41. Velde, K.V.d. and E. Baetens, Thermal and Mechanical Properties of Flax Fibres as Potential Composite Reinforcement. Macromolecular Materials and Engineering, 2001. 286(6): p. 342-349.

42. Martin, N., N. Mouret, P. Davies, and C. Baley, Influence of the degree of retting of flax fibers on the tensile properties of single fibers and short fiber/polypropylene composites. Industrial Crops and Products, 2013. 49(0): p. 755-767.

43. Baley, C., F. Busnel, Y. Grohens, and O. Sire, Influence of chemical treatments on surface properties and adhesion of flax fibre-polyester resin. Composites Part A: Applied Science and Manufacturing, 2006. 37(10): p. 1626-1637.

44. Esau, K., Anatomy of Seed Plants. 1977, New York: Wiley.

45. Gorshkova, T.A., S.B. Chemikosova, V.V. Lozovaya, and N.C. Carpita, Turnover of Galactans and Other Cell Wall Polysaccharides during Development of Flax Plants. Plant Physiol., 1997. 114(2): p. 723-729.

46. Gorshkova, T. and C. Morvan, Secondary cell-wall assembly in flax phloem fibres: Role of galactans. Planta, 2006. 223(2): p. 149-158.

47. Snegireva, A.V., M.V. Ageeva, S.I. Amenitskii, T.E. Chernova, M. Ebskamp, and T.A. Gorshkova, Intrusive growth of sclerenchyma fibers. Russian Journal of Plant Physiology, 2010. 57(3): p. 342-355.

48. Ageeva, M.V., B. Petrovská, H. Kieft, V.V. Sal'nikov, A.V. Snegireva, J.E.G. Dam, W.L.H. Veenendaal, A.M.C. Emons, T.A. Gorshkova, and A.A.M. Lammeren, Intrusive growth of flax phloem fibers is of intercalary type. Planta, 2005. 222(4): p. 565-574.

49. Gorshkova, T.A., V.V. Sal'nikov, S.B. Chemikosova, M.V. Ageeva, N.V. Pavlencheva, and J.E.G. Van Dam, The snap point: a transition point in Linum usitatissimum bast fiber development. Industrial Crops and Products, 2003. 18: p. 213-221.

50. Snegireva, A.V., M.V. Ageeva, V.N. Vorob'ev, A.V. Anisimov, and T.A. Gorshkova, Plant fiber intrusive growth characterized by NMR method. Russian Journal of Plant Physiology, 2006. 53(2): p. 163-168.

51. Bos, H., The Potential of Flax Fibres as Reinforcement for Composite Materials. 2004, Technische Universiteit Eindhoven: Eindhoven.

52. Gorshkova, T.A., V.V. Salnikov, N.M. Pogodina, S.B. Chemikosova, E.V. Yablokova, A.V. Ulanov, M.V. Ageeva, J.E.G. van Dam, and V.V. Lozovaya, Composition and Distribution of Cell Wall Phenolic Compounds in Flax (Linum usitatissimum L.) Stem Tissues. Annals of Botany, 2000. 85(4): p. 477-486.

53. Burgert, I., Exploring the micromechanical design of plant cell walls. American Journal of Botany, 2006. 93(10): p. 1391-1401.

54. Altaner, C.M. and M.C. Jarvis, Modelling polymer interactions of the molecular Velcro' type in wood under mechanical stress. Journal of Theoretical Biology, 2008. 253(3): p. 434-445.

55. Peterlin, A. and P. Ingram, Morpholgy od seondary wall fibrils in cotton. Textile research journal, 1970. 40: p. 345-351.

56. Fratzl, P., I. Burgert, and H. Gupta, On the role of interface polymers for the mechanics of natural polymeric composites. Phys. Chem.Chem.Phys, 2004. 6: p. 5575-5579.

57. Bos, H.L., The potential of flax fibres as reinforcement for composite materials-Thesis report. Eindhoven, 2004.

58. His, I., C. Andème-Onzighi, C. Morvan, and A. Driouich, Microscopic Studies on Mature Flax Fibers Embedded in LR White: Immunogold Localization of Cell Wall Matrix Polysaccharides. The Journal of Histochemistry \& Cytochemistry, 2001. 49(12): p. 1525-1535.

59. Kutschera, U., The Growing Outer Epidermal Wall: Design and Physiological Role of a Composite Structure. Annals of Botany, 2008. 101(5): p. 615-621.

60. Gorshkova, T., N. Brutch, B. Chabbert, M. Deyholos, T. Hayashi, S. Lev-Yadun, E.J. Mellerowicz, C. Morvan, G. Neutelings, and G. Pilate, Plant Fiber Formation: State of the Art, Recent and Expected Progress, and Open Questions. Critical Reviews in Plant Sciences, 2012. 31(3): p. 201-228. 
61. Hearle, J.W.S., The fine structure of fibers and crystalline polymers. III. Interpretation of the mechanical properties of fibers. Journal of Applied Polymers Science, 1963. 7: p. 1207-1223.

62. Gorshkova, T. and C. Morvan, Secondary cell-wall assembly in flax phloem fibres; role of galactans. Planta, 2006. 223: p. 149-58.

63. Keckes, J., I. Burgert, K. Fruhmann, M. Muller, K. Kolln, and M. Hamilton, Cell-wall recovery after irreversible deformation of wood. Nature Materials, 2003. 2: p. 810-4.

64. Fratzl, P., I. Burgert, and H.S. Gupta, On the role of interface polymers for the mechanics of natural polymeric composites. Physical Chemistry Chemical Physics, 2004. 6(24): p. 5575-5579.

65. Burgert, I., Exploring the micromechanical design of plant cell walls. Am. J. Bot., 2006. 93(10): p. 13911401.

66. Alix, S., E. Philippe, C. Morvan, and C. Baley, Putative role of pectins in the tensile properties of flax fibres: a comparison between linseed and flax fibers varieties, in Pectins and pectinases. 2008: Wageningen.

67. Alix, S., E. Philippe, C. Morvan, and C. Baley, Putative role of pectins in the tensiles properties of flax fibres: a comparison between linseed and flax fibres varieties, in Pectins and Pectinases. 2008: Wageningen, The Netherlands.

68. Morvan, C., C. Andème-Onzighi, R. Girault, D.S. Himmelsbach, A. Driouich, and D.E. Akin, Building flax fibres: more than one brick in the walls. Plant Physiology and Biochemistry, 2003. 41(11-12): p. 935-944.

69. Morvan, C., Le lin, les fibres cellulosiques: leurs parois: variabilité et défauts, in Ecole d'été. 2010: Lorient.

70. Zykwinska, A., J.-F. Thibault, and M.-C. Ralet, Organization of pectic arabinan and galactan side chains in association with cellulose microfibrils in primary cell walls and related models envisaged. Journal of Experimental Botany, 2007. 58(7): p. 1795-1802.

71. Cosgrove, D.J., Growth of the plant cell wall. Nat Rev Mol Cell Biol, 2005. 6(11): p. 850-861.

72. Gorshkova, T., O. Gurjanov, P. Mikshina, N. Ibragimova, N. Mokshina, V. Salnikov, M. Ageeva, S. Amenitskii, T. Chernova, and S. Chemikosova, Specific type of secondary cell wall formed by plant fibers. Russian Journal of Plant Physiology, 2010. 57(3): p. 328-341.

73. Bledzki, A.K. and J. Gassan, Composites reinforced with cellulose based fibres. Progress in Polymer Science, 1999. 24: p. 221-274.

74. Vincent, J., From cellulose to cell. J Exp Biol, 1999. 202(23): p. 3263b-3268.

75. Baley, C., C. Morvan, and Y. Grohens, Influence of the Absorbed Water on the Tensile Strength of Flax Fibers. Macromolecular Symposia, 2005. 222(1): p. 195-202.

76. Baley, C., A. Le Duigou, A. Bourmaud, and P. Davies, Influence of drying on the mechanical behaviour of flax fibres and their unidirectional composites. Composites Part A: Applied Science and Manufacturing, 2012. 43(8): p. 1226-1233.

77. Girault, R., F. Bert, C. Rihouey, A. Jauneau, C. Morvan, and M. Jarvis, Galactans and cellulose in flax fibres: putative contributions to the tensile strength. International Journal of Biological Macromolecules, 1997. 21(1-2): p. 179-188.

78. Gassan, J. and A. Bledzki, Thermal degradation of flax and jute fibers. Journal of Applied Polymers Science, 2001. 82(6): p. 1417-22.

79. Placet, V., Characterization of the thermo-mechanical behaviour of Hemp fibres intended for the manufacturing of high performance composites. Composites Part A: Applied Science and Manufacturing Special Issue: 15th French National Conference on Composites - JNC15, 2009. 40(8): p. 1111-1118.

80. Zafeiropoulos, N.E., C.A. Baillie, and F.L. Matthews, A study of transcrystallinity and its effect on the interface in flax fibre reinforced composite materials. Composites Part A: Applied Science and Manufacturing, 2001. 32(3-4): p. 525-543.

81. Hearle, J., The fine structure of fibers and crystalline polymers. III. Interpretation of the mechanical properties of fibers. J. App Polym. Sci., 1963. 7: p. 1207-23.

82. Zafeiropoulos, N.E., C.A. Baillie, and J.M. Hodgkinson, Engineering and characterisation of the interface in flax fibre/polypropylene composite materials. Part II. The effect of surface treatments on the interface. Composite Part A: Applied Science and Manufacturing, 2002. 33(9): p. 1185-1190. 
83. Zafeiropoulos, N.E., P. Vickers, C. Baillie, and J. Watts, An experimental investigation of modified and unmodified flax fibres with XPS, ToF-SIMS ans ATR-FTIR. Joural of Materials Science, 2003. 38: p. 39033914.

84. Bismarck, A., I. Aranberri-Askargorta, J. Springer, T. Lampke, B. Wielage, A. Stamboulis, I. Shenderovich, and H. Limbach, Surface characterization of flax, hemp and celullose fibers ; surface properties and the water uptake behavior. polymer composites, 2002. 23(5): p. 872-894.

85. le Duigou, A., A. Bourmaud, E. Balnois, P. Davies, and C. Baley, Improving the interfacial properties between flax fibres and PLLA by a water fibre treatment and drying cycle. Industrial Crops and Products, 2012. 39(0): p. 31-39.

86. Busnel, F., E. Balnois, C. Baley, and Y. Grohens, Influence des traitements chimiques sur les propriétés de surface des fibres de lin- Approche nano et macroscopiques. Revue des composites et matériaux avancésrenforcemnt des polymères par des fibres végétales, 2006. 16: p. 75-87.

87. Baley, C., F. Busnel, Y. Grohens, and O. Sire, Influence of chemical treatments on surface properties and adhesion of flax fibre-polyester resin. Composite Part A: Applied Science and Manufacturing, 2006. 37(10): p. 1626-1637.

88. Heng, Y., F. Pearse, F. Thielmann, T. Lampke, and A. Bismarck, Methods to determine surface energies of natural fibres : A review. Comp Interface, 2007. 14(7-9): p. 581-604.

89. Van de Welde, K. and P. Kiekens, Wettability of natural fibres used as reinforcement for composites. Die Angewandte Makromolekulare Chemie, 1999. 271: p. 87-93.

90. Cantero, G., A. Arbelaiz, R. Llano-Ponte, and I. Mondragon, Effects of fibre treatment on wettability and mechanical behaviour of flax/polypropylene composites. Composites Science and Technology, 2003. 63(9): p. 1247-1254.

91. Aranberri-Askargorta, I., T. Lampke, and A. Bismarck, Wetting behavior of flax fibers as reinforcement for polypropylene. Journal of Colloid and Interface Science, 2003. 263(2): p. 580-589.

92. Cordeiro, N., C. Gouveia, and M.J. John, Investigation of surface properties of physico-chemically modified natural fibres using inverse gas chromatography. Industrial Crops and Products, 2011. 33(1): p. 108-115.

93. Raj, G., E. Balnois, C. Baley, and Y. Grohens, Probing cellulose/polylactic acid interactions in model biocomposite by colloidal force microscopy. Colloids and Surfaces A: Physicochemical and Engineering Aspects, 2009. 352(1-3): p. 47-55.

94. Van Hazendonk, J., J. Van der Putten, J. Keurentjes, and A. Prins, A simple experimental method for the measurement of the surface tension of cellulosic fibres and its relation with chemical composition. Colloids and Surfaces A: Physicochemical and Engineering Aspects, 1993. 81: p. 251-261.

95. Zykwinska, A., J.-F. Thibault, and M.-C. Ralet, Competitive binding of pectin and xyloglucan with primary cell wall cellulose. Carbohydrate Polymers, 2008. 74(4): p. 957-961.

96. Davies, G.C. and D.M. Bruce, Effect of Environmental Relative Humidity and Damage on the Tensile Properties of Flax and Nettle Fibers. Textile Research Journal, 1998. 68(9): p. 623-629.

97. Barsberg, S. and L. Thygesen, Nonequilibrium phenomena influencing the wetting behavior of plant fibers. Journal of colloid and interface science, 2001. 234: p. 59-67.

98. Kabir, M.M., H. Wang, K.T. Lau, and F. Cardona, Chemical treatments on plant-based natural fibre reinforced polymer composites: An overview. Composites Part B: Engineering, 2012. 43(7): p. 2883-2892.

99. Faruk, O., A.K. Bledzki, H.-P. Fink, and M. Sain, Biocomposites reinforced with natural fibers: 20002010. Progress in Polymer Science, 2012. 37(11): p. 1552-1596.

100. Li, X., L. Tabil, and S. Panigrahi, Chemical Treatments of Natural Fiber for Use in Natural FiberReinforced Composites: A Review. Journal of Polymers and the Environment, 2007. 15(1): p. 25-33.

101. Herrera-Franco, P. and L. Drzal, Comparison of methods for the measurement of fibre/matrix adhesion in composites. Comp. Sci. Technol., 1992. 23(1): p. 2-27.

102. Miller, B., A microbond method for determination for determination of the shear strength of a fiber/resin interface. Comp. Sci. Technol., 1987. 28: p. 17-32.

103. Liu, C. and J. Nairn, Analytical and experimental methods for a fracture mechanics interpretation of the microbond test including the effects of friction and thermal stresses. International Journal of Adhesion and Adhesives, 1999. 19(1): p. 59-70. 
104. Ash, J.T., W.M. Cross, D. Svalstad, J.J. Kellar, and L. Kjerengtroen, Finite element evaluation of the microbond test: meniscus effect, interphase region, and vise angle. Composites Science and Technology, 2003. 63(5): p. 641-651.

105. Hodzic, A., S. Kalyanasundaram, J.K. Kim, A.E. Lowe, and Z.H. Stachurski, Application of Nanoindentation, Nano-scratch ang Single Fibre Tests in Investigation of Interphases in Composite Materials. Micron 2001. 32: p. 765-775.

106. Kessler, H., T. Schüller, W. Beckert, and B. Lauke, A fracture-mechanics model of the microbond test with interface friction. Composites Science and Technology, 1999. 59(15): p. 2231-2242.

107. Pisanova, E., S. Zhandarov, E. Mäder, I. Ahmad, and R.J. Young, Three techniques of interfacial bond strength estimation from direct observation of crack initiation and propagation in polymer-fibre systems. Composite Part A: Applied Science and Manufacturing, 2001. 32(3-4): p. 435-443.

108. Day, R.J. and J.V.C. Rodrigez, Investigation of the micromechanics of the microbond test. Composites Science and Technology, 1997. 58(6): p. 907-914.

109. Eichhorn, S. and R. Young, Deformation micromechanics of natural cellulose fibre networks and composites. Composites Science and Technology, 2003. 63(9): p. 1225-1230.

110. Le Duigou, A., P. Davies, and C. Baley, Interfacial bonding of flax/Poly(L-Lactide) biocomposites. Composites Science and Technology, 2010. 70(2): p. 231-239.

111. Baley, C., Y. Grohens, F. Busnel, and P. Davies, Application of interlaminar test to marine composites. Relation between glass fibre/polymer interfaces and interlaminar properties of marine composites. Applied Composite Materials, 2004. 11: p. 77-98.

112. Raj, G., E. Balnois, C. Baley, and Y. Grohens, Role of polysaccharides on mechanical and adhesion properties of flax fibres in flax/PLA biocomposite. International Journal of Polymer Science, 2011. 2011.

113. Raj, G., E. Balnois, C. Baley, and Y. Grohens, Colloid Force measurements between Cellulose and Polylactic Acid (PLA). RCMA, 2008. 18(2): p. 177-83.

114. Tissaoui, J., Effects of Long-Term Creep on the Integrity of Modern Wood Structures, in Civil Engineering. 1996, Virginia Polytechnic Institute and State University.

115. Sernek, Comparative Analysis of Inactivated Wood Surface, in Civil Engineering. 2002, Virginia Polytechnic Institute and State University.

116. Christiansen, A., How overdrying reduces its bonding to phenol formlaldehyde adhesives : A critical review of the literature. Part I Physical responses. Wood and fiber Science, 1990. 22(4): p. 441-449.

117. Christiansen, A., How overdrying reduces its bonding to phenol formaldehyde adhesives: A critical review of the literature. Part II Chemical reactions. Wood and fiber Science, 1991. 23(1): p. 69-84.

118. Gérardin, P., M. Petric, M. Petrissans, J. Lambert, and J.-J. Ehrhrardt, Evolution of wood surface free energy after heat treatment. Polymer Degradation and Stability, 2007. 92(4): p. 653-657.

119. Baley, C., Y. Perrot, F. Busnel, H. Guezenoc, and P. Davies, Transverse tensile behaviour of unidirectional plies reinforced with flax fibres. Materials Letters, 2006. 60(24): p. 2984-2987.

120. Hugues, M., G. Sèbe, J. Hague, C. Hill, M. Spear, and L. Mott, An investigation into the effects of microcompressive defects on interphase behaviour in hemp-epoxy composites using half-fringe photoelasticity. Composite Interfaces, 2000. 7(1): p. 13-29.

121. Bos, H., M. Van Den Oever, and O. Peters, Tensile and compressive properties of flax fibres for natural fibre reinforced composites. J Mater Sci, 2002. 37(8): p. 1683-1692.

122. Rask, M., B. Madsen, B.F. Sørensen, J.L. Fife, K. Martyniuk, and E.M. Lauridsen, In situ observations of microscale damage evolution in unidirectional natural fibre composites. Composites Part A: Applied Science and Manufacturing, 2012. 43(10): p. 1639-1649.

123. Andersons, J. and R. Joffe, Estimation of the tensile strength of an oriented flax fiber-reinforced polymer composite. Composites Part A: Applied Science and Manufacturing, 2011. 42(9): p. 1229-1235.

124. Bourmaud, A., G. Ausias, G. Lebrun, M.L. Tachon, and C. Baley, Observation of the structure of a composite polypropylenelflax and damage mechanisms under stress. Industrial Crops and Products, 2013. 43(0): p. 225-236.

125. Bay, R.S. and C.L. Tucker, Fiber orientation in simple injection moldings. Part I: Theory and numerical methods. Polymer Composites, 1992. 13(4): p. 317-331. 
126. Bay, R.S. and C.L. Tucker, Fiber orientation in simple injection moldings. Part II: Experimental results. Polymer Composites, 1992. 13(4): p. 332-341.

127. Zhou, Q., L. Greffe, M. Baumann, E. Malmstrom, T. Teeri, and H. Brumer, Use of xyloglucan as a molecular anchor for the elaboration of polymers from cellulose surfaces : A general route for the design of biocomposites. Macromolecules, 2005. 38: p. 3547-3549

128. Mano, B., J.R. Araújo, M.A.S. Spinacé, and M.A. De Paoli, Polyolefin composites with curaua fibres: Effect of the processing conditions on mechanical properties, morphology and fibres dimensions. Composites Science and Technology, 2010. 70(1): p. 29-35.

129. Shon, K. and J.L. White, A comparative study of fiber breakage in compounding glass fiber-reinforced thermoplastics in a buss kneader, modular Co-rotating and counter-rotating twin screw extruders. Polymer Engineering \& Science, 1999. 39(9): p. 1757-1768.

130. Joseph, P.V., K. Joseph, and S. Thomas, Effect of processing variables on the mechanical properties of sisal-fiber-reinforced polypropylene composites. Composites Science and Technology, 1999. 59(11): p. 1625-1640.

131. Siaotong, B., L. Tabil, S. Panigrahi, and W. Crerar, Determination of optimum extrusion parameters in compounding flax fibres reinforced polyethylene composites, in American Society of Agricultural and Biological Engineers. 2006.

132. Li, X., L. Tabil, S. Panigrahi, and L.-G. Tabil, A study on flax fibre reinforced polyethylene biocomposites by injection moulding. Applied Engineering in Agriculture, 2009. 25: p. 525-531. 
Figure 1. Stem fibre section and details of an elementary fibre bundle

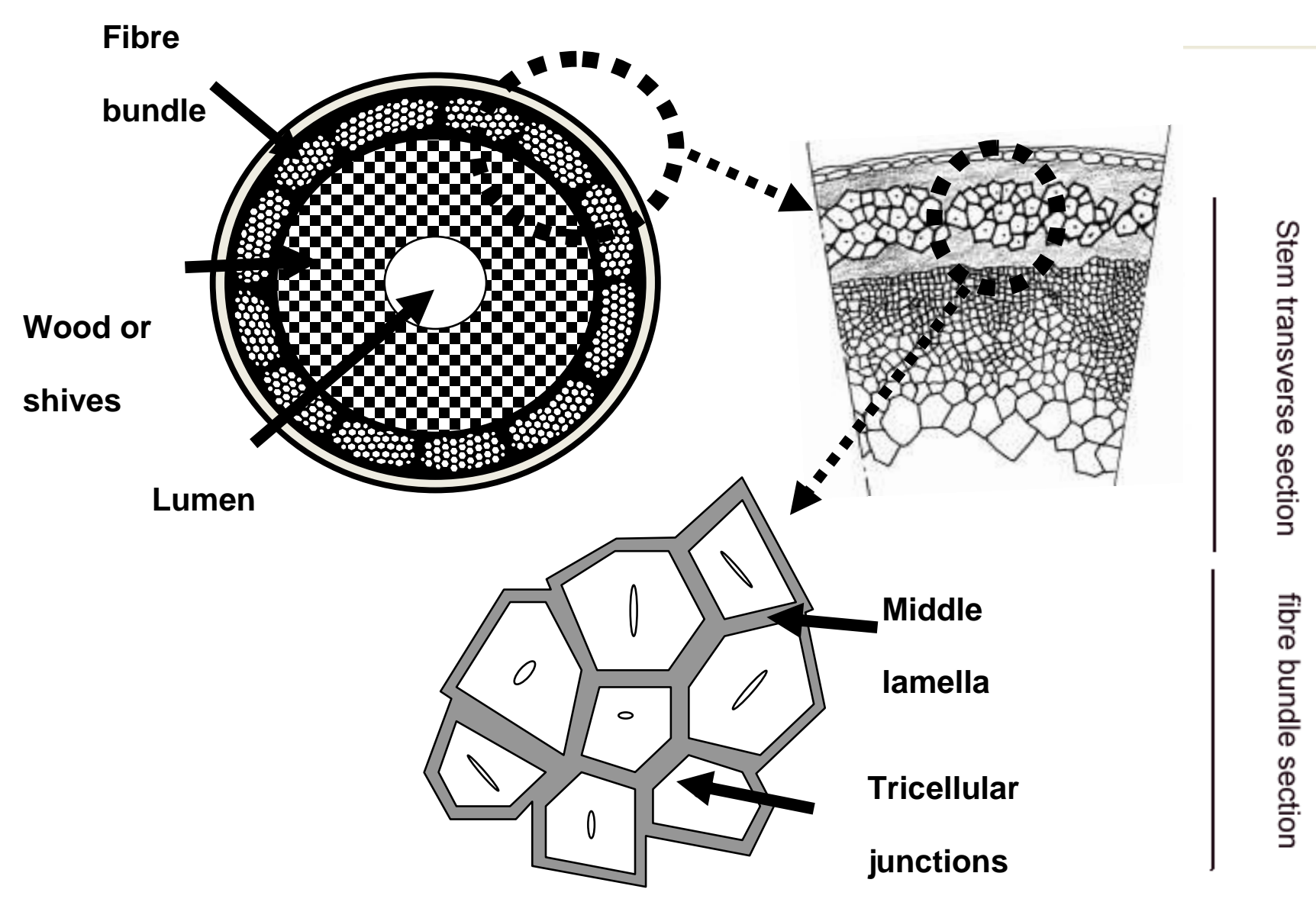


Figure 2. Schematic representation of flax fibre showing helix arrangement of cellulose fibrils and of the chemical structures in the S2 layer of flax cellulosic fibres. (EH: matrix non cellulosic polymers and EOH: structural non cellulosic polymers) [1].

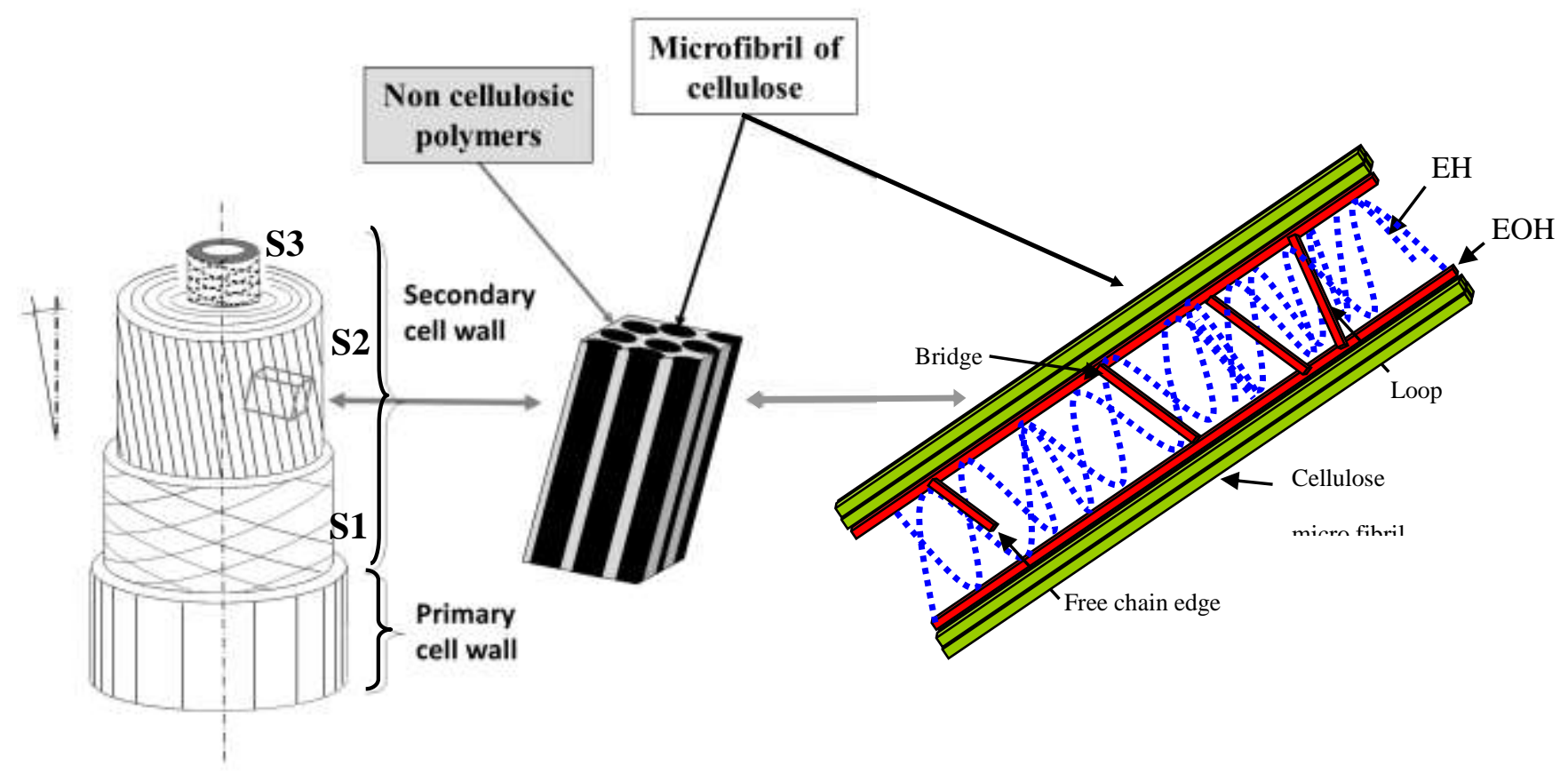


Figure 3. SEM images of flax fibres showing different surface state according to the degree of retting
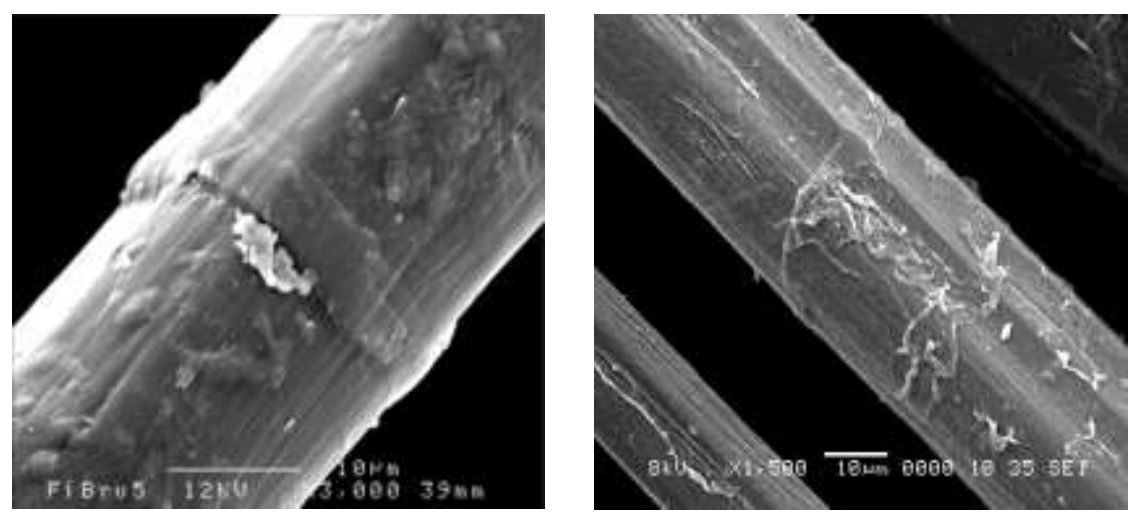
Figure 4. Fibre/matrix interface characterization by using micro drop debonding (4.A and 4.B) and peeling observation (4.C)
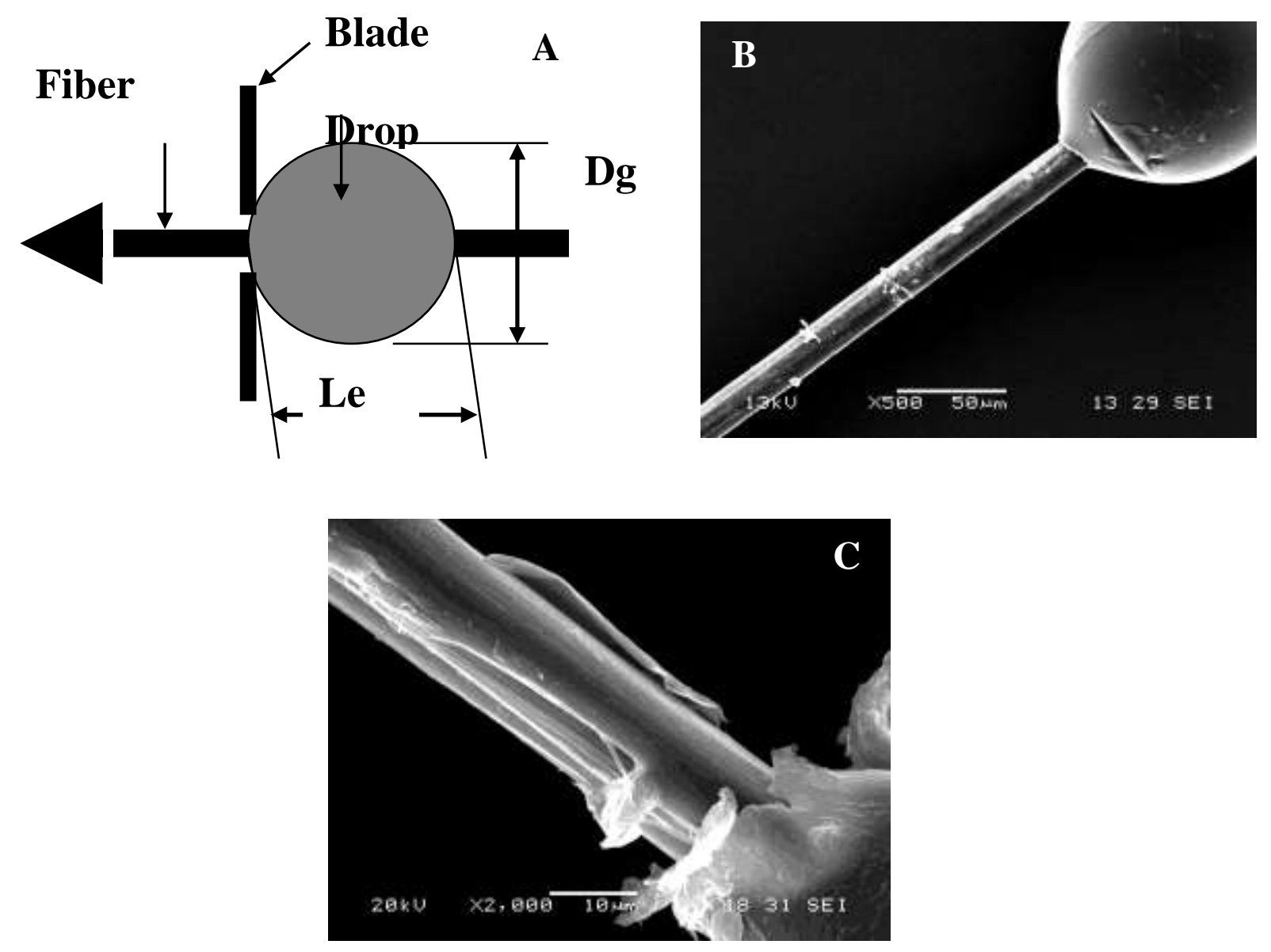
Figure 5. Development of crack in a UD polyester/flax within a bundle of flax fibre (A), at the fibre/matrix interface $(B)$ and failure within a single fibre $(C)$ [2]. 


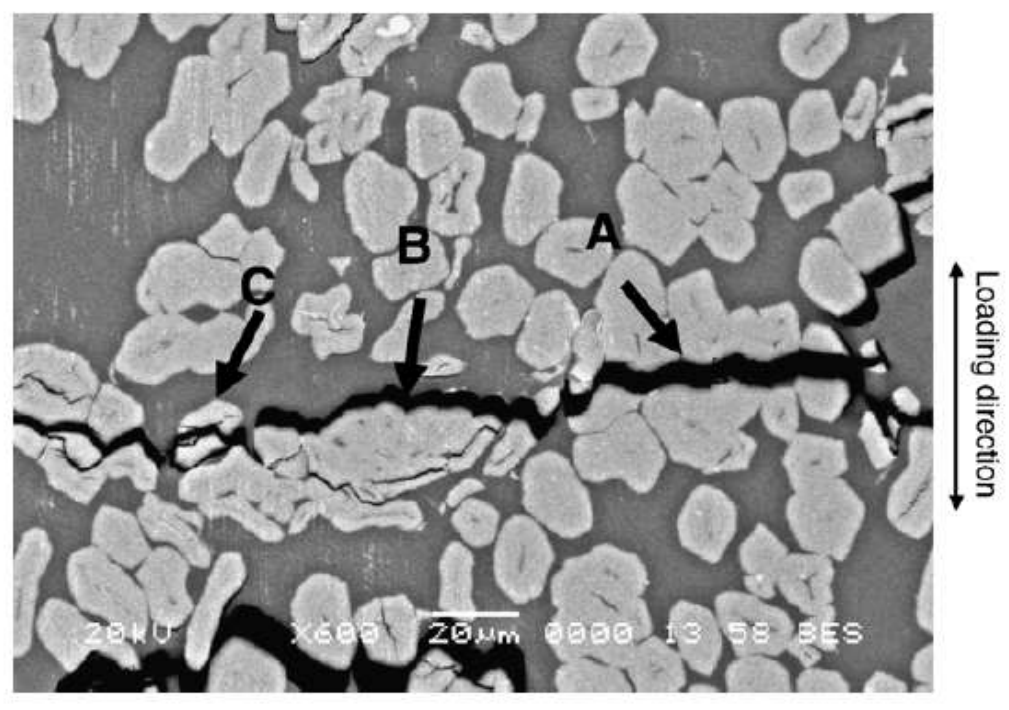

